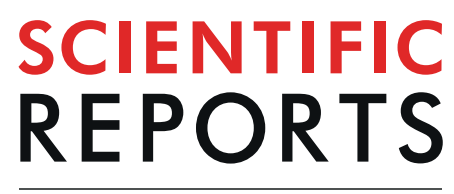

natureresearch

\title{
OPEN Publisher Correction: In Utero Gene Therapy (IUGT) Using GLOBE Lentiviral Vector Phenotypically Corrects the Heterozygous Humanised Mouse Model and Its Progress Can Be Monitored Using MRI Techniques
}

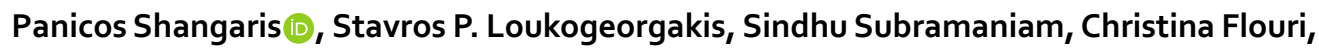
Laurence H. Jackson, Wei Wang, Michael P. Blundell, Shanrun Liu, Simon Eaton 1 Nahla Bakhamis, Durrgah Latchumi Ramachandra, Panayiotis Maghsoudlou, Luca Urbani, Simon N. Waddington $D^{D}$, Ayad Eddaoudi ${ }^{\circ}$, Joy Archer, Michael N. Antoniou $\mathbb{D}^{\text {, }}$ Daniel J. Stuckey, Manfred Schmidt, Adrian J. Thrasher, Thomas M. Ryan, Paolo De Coppi $i$ \& Anna L. David (1)

Correction to: Scientific Reports https://doi.org/10.1038/s41598-019-48078-4, published online 12 August 2019

In the original version of this Article, the author Paolo De Coppi was incorrectly indexed.

Additionally, Paolo De Coppi and Anna L. David were omitted as equally contributing senior authors.

These errors have now been corrected in the PDF and HTML versions of the Article.

(c) (i) Open Access This article is licensed under a Creative Commons Attribution 4.0 International cal License, which permits use, sharing, adaptation, distribution and reproduction in any medium or format, as long as you give appropriate credit to the original author(s) and the source, provide a link to the Creative Commons license, and indicate if changes were made. The images or other third party material in this article are included in the article's Creative Commons license, unless indicated otherwise in a credit line to the material. If material is not included in the article's Creative Commons license and your intended use is not permitted by statutory regulation or exceeds the permitted use, you will need to obtain permission directly from the copyright holder. To view a copy of this license, visit http://creativecommons.org/licenses/by/4.0/.

(c) The Author(s) 2019 